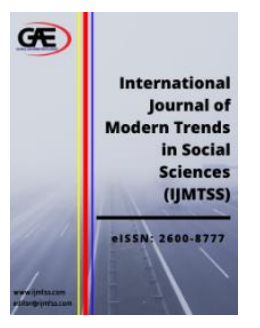

International Journal of Modern Trends in Social Sciences (IJMTSS)

Journal Website: http://ijmtss.com/ eISSN: $2600-8777$

\title{
FACTORS AFFECTING THE PERFORMANCE OF EMPLOYEE IN WORKPLACE
}

\author{
Nur Munirah Bustamam ${ }^{1}$, Noor Fazira Che $\mathrm{Choh}^{2}$, Dr. Johari Shaari ${ }^{3}$, Razali Muda ${ }^{4}$
}

$1 \quad$ Faculty of Business and Finance, TWINTECH International University College of Technology, Malaysia Email: munirah.fbf@twintech.edu.my

2 BBA (Hons) International Business, TWINTECH International University College of Technology, Malaysia Email: noorfazira05@gmail.com

3 Faculty of Business and Finance, TWINTECH International University College of Technology, Malaysia Email: johari.fbf@twintech.edu.my

$4 \quad$ Faculty of Business and Finance, TWINTECH International University College of Technology, Malaysia Email: razali.fbf@twintech.edu.my

\section{Article Info:}

Article history:

Received date:.21.01.2020

Revised date: 23.01 .2020

Accepted date: 06.02.2020

Published date: 15.03.2020

\section{To cite this document:}

Bustaman, N. M., Choh, N. F. C., Shaari, J., \& Muda, R. (2020). Factors Affecting the Performance of Employee in Workplace. International Journal of Modern Trends in Social Sciences, 3 (11), 69-79.

DOI: 10.35631/IJMTSS.311005.

\begin{abstract}
:
The aim of the study was to dissect the undeviating effects of work-life balance, training, and rewards on employee performance. These variables were identified based on the key outcomes of employee engagement performance. The methodology consists of a thorough literature review after which a model was framed for employee performance. A survey-based empirical study with 101 respondents working in the private sector was conducted using convenience sampling. Structural Equation Model (SEM) was used to validate the model and to find the impact of work-life balance, training, and rewards on employee performance. Upon SEM analysis, the various factors to predict employee performance resulted in a significant $(\beta=0.726) ;(\mathrm{P}<0.001)$ that indicates that only the work-life balance factor is significant in predicting the dependent variable. However, the findings from this study showed training and rewards do not significantly affect the performance of the employee. The study implies that enhancing work-life balance results in employees having a healthy engagement with their work. Thereby his/ her performance also increases that contribute to the effectiveness of the organisation.
\end{abstract}

Keywords:

Work Life Balance, Training, Reward

\section{Introduction}

Employee performance has been a subject of great interest to organizations and researchers alike. Employee performance is the successful key to achieve organizational goals and surviving competitive. Therefore, organization always looks for good employees to leads their 
organizational mission and vision. It has become important part of organization not only for government but private sectors as well (Aboazoum, Nimran, \& Musadieq, 2015). In addition, organizations can successfully compete if organization can improve employee's performance at the workplace (Hijry \& Haleem, 2017).

Every organization needs to set up a number of strategies in order to improve employee performance towards the achievement of predetermined goals. Reward system has been identified as a main tool to maximize on the employee performance. As employee performance will be more effective to high reward system (Ibrar \& Khan, 2015). Training also has been identified as one determined of employee performance. It has the distinct role in the achievement of an organizational goal by incorporating the interests of organization and the workforce (Zahid Hussain Bhat, 2011). Generally, highly skilled employees are the asset of company. Other than reward system and training program, it is believed that work-life balance also will influences employee performance. Work-life balance has become major concern to those wishing to have good life quality (Soomro, Breitenecker, \& Shah, 2018). Employee is a human being and dealing with people means we are dealing with emotion and psychology. It is believed that a happy employee can perform better in their job. Therefore, this paper is to test this conceptual model and to determine the impact of reward, training and work-life balance impact on employee behaviour.

\section{Literature Review}

\section{Employee Performance}

Employee performance is the way to perform job task according to the prescribed job (Shaikh, Tunio, \& Shah, 2017). It also known as a precursor to organizational success (Ramlall, 2008); (Shaikh, Tunio, \& Shah, 2017). Additionally, employee performance contributes to the general enhancement of organization process specifically in efficiency and productivity (S. H. Abualoush, Obeidat, Tarhini, Masa'deh, \& Al-Badi, 2018). Hence, it also dictates how employees contribute to the organization. The output quantity, work attendance, and accommodating attitude are the examples of end results of employees contribution to their organization (S. Abualoush, Masa'deh, Bataineh, \& Alrowwad, 2018).

\section{The Factors That Affect Employees Performance}

\section{Work Life Balance}

Work-life balance has now taken a central position in the employment practices and policies of employers (Kim, 2014), initially regarded as an issue to be managed by the individual employee,. It is believed that work-life balance issues is positively linked to the numerous advantages that have been discovered as correlated with work-life balance for both the employer and employee context (Emslie \& Hunt, 2009); (Jones, Burke, \& Westman, 2013). In the employees' perspective, improved work-life balance directly affects their psychological well-being whereas organisations are competent to boost affective organisational commitment, job satisfaction, worker engagement, organisational citizenship behaviours and employee productivity through appropriate work-life balance practices and policies (Cegarra-Leiva, Eugenia Sánchez-Vidal, \& Cegarra-Navarro, 2012); (Emslie \& Hunt, 2009); (Jones et al., 2013). Clearly, the issue of diminishing work-life balance is present in all work sectors. However it is more common to particular industries due to the work nature (Soomro, Breitenecker, \& Shah, 2018; (Bataineh, 2019); (Mendis \& Weerakkody, 2018). For instance, industries such as Pharmaceutical industries have high incidences of diminishing work-life 
balance due to the complex and demanding nature of the conditions under which people work in these sectors by (Bataineh, 2019).

\section{Reward}

Globally, employers are looking for superior strategies to motivate the employee to perform at optimum. Appropriate reward system is one of such strategies. Reward system attracts and retains top performing employee. It also continuously inspires employee toward excellent performance (Downes \& Choi, 2014). Reward is a focal point of employment relationship. The combination of financial and non-financial rewards is the total reward available for employees. The total reward approach is holistic; reliance is not placed on one or two reward mechanisms operating in isolation, account is taken of every way in which people can be rewarded and obtain satisfaction through their work (Armstrong, 2009). Organizations should have an effective rewards and recognition program in place (Ali \& Ahmed, 2010) in order to boost staff morale, motivation, and benefit to the organization in the long term. A change in the reward system will have a positive impact on the employees' motivation. For instance, if the reward system or scale is improved, it will have a positive impact on the motivation of employees, and vice versa (Hafiza, Shah, \& Jamsheed, 2011).

\section{Training}

In the worldwide, organizations have been enrolling their employees in training programs to develop their skills, knowledge, and capabilities. Most of them facilitate the training through the development of programs with the ability to meet their employee's needs (Halawi \& Haydar, 2013). Commonly, organizations have sought to rely on improved skills, knowledge, and capability of the talented workforce to create competitive advantage (Lin \& Hsu, 2017). In order to develop the desirable skills, knowledge, and capability of employee and position them to perform their responsibilities, managers in charge of human resource training design different training programs (Lakra, 2016). The training programs not simply target to develop the familiarity of employees on job responsibilities, but it also helps to encourage employees to develop more job commitment. (Huang \& Jao, 2016) have explained that organizations designing a training program to prepare their employees to perform their jobs correctly and according to the laid down standards. (Khan \& Baloch, 2017) opined that majority of organizations prefer to invest in different programs that create new skills through long-term planning. This is to enable them to adapt to any current and future uncertainties. Therefore, they ensure that they improve the performance of their employees through superior levels of commitments and motivation.

\section{Conceptual Framework}

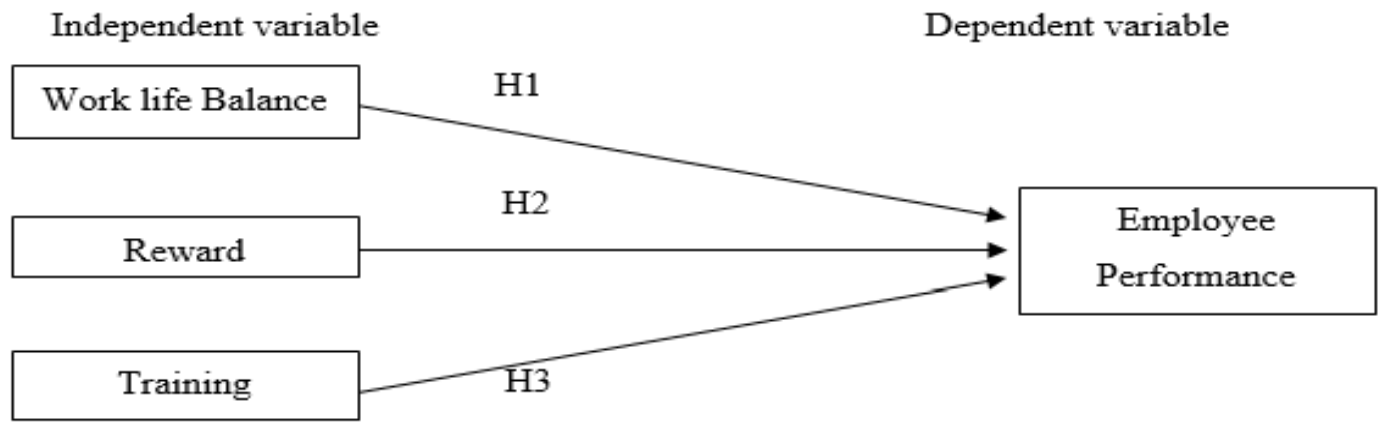

Figure 1 Conceptual Framework 
Hypotheses:

H1: Work life balance has significant affect to employee performance.

$\mathrm{H} 2$ : Reward has significant affect to employee performance.

H3: Training has significant affect to employee performance.

\section{Methodology}

The objectives of this study are to explore effects of work life balance, reward and training on employee performance The study is expected to be a constructive input for organization in understanding the employee's performance, so that they can help create value in line with the needs, wants and expectations of workers and other this research is expected to be a new breakthrough for the benefit of science especially for management science.

\section{Respondents}

Samples were collected from private workers via online survey using convenience sampling technique. The number of sample collection was 101 in total within three months from $17^{\text {th }}$ April to $2^{\text {nd }}$ July, 2019. According to (Anderson \& Gerbing, 1988) to satisfy a structure equation modelling (SEM) analysis needs samples between 100 and 150 . Therefore, the study meets this basic requirement.

\section{Instrument}

The questionnaire consists of six sections. The first section collects the respondent's demographic data with four items such as gender, age, duration of service with current employer and education level. The second section consists of five (5) items of employee performance. The third section deals with reward measurement with four (4) items. The fifth section deals with training measurement with three (3) items and last section deals with work life balance with four (4) items. The section from respondent information measured by a categorical scale, all items of the second to six section measured by a 5-point Likert-type scale from "Strongly Disagree (=1) to Strongly Agree (=5).

\section{Results}

\section{Sample Characteristics}

Of the 103 questionnaires distributed, 101 were retrieved, resulting in 98 per cent response rate. Respondents were asked about their gender, age, education level and year of work experience. This information was required to ensure that the sample that participated in the study have similar distribution of the respondents by characteristics to that of the population it was drawn from. This determines the accuracy and representatives of information drawn from the sample to the population.

From the survey, majority of respondents were females $\mathrm{f}=54$ (53.5 percent) whilst males with $\mathrm{f}=47$ ( 46.5 percent). The result of age show that $\mathrm{f}=94$ (93.1 percent) of respondent were age below 30 years old while $\mathrm{f}=7$ ( 6.9 percent) were age at 30 to 39 years old. The biggest proportion $\mathrm{f}=90$ ( 89.1 percent) of the respondents had worked for a period of below 5 years, followed by those who had worked for a period of 6 to 10 years $f=9$ ( 8.9 percent). Those who had worked for above 10 years were $f=1(1.0$ percent $)$. The survey result found that $f=36$ (35.6 percent) of the respondent has certificate as highest education level, followed by $\mathrm{f}=43$ (42.6 percent) are having diploma while $f=20$ (19.8) respondent are having degree. 


\section{Reliability and Validity}

\section{Internal Consistency}

Two measures were used to evaluate the internal consistency of the constructs. Reliability is identified by Cronbach's alpha with a minimum of 0.70 (Allen, 1984); (Nunnally, 1979) and the average variance extracted (AVE) which estimates the amount of variance captured by a construct's measure relative to random measurement error (Claes \& David F., 1981). An AVE greater than 0.50 is considered to support internal consistency (Bagozzi \& Yi, 1988).

Convergent validity measures the extent to which the items of a scale that are theoretically related are correlated. According to Hair et al. (2010) a composite reliability of 0.70 or above and an average variance extracted of more than 0.50 are deemed acceptable. As can be seen from Table 1, all the composite reliability values are above 0.70 and the average variance extracted is all above 0.50 . Therefore, we can conclude that convergent validity has been established.

Table 1: Result of CFA for Measurement Model

\begin{tabular}{|c|c|c|c|c|c|}
\hline \multirow[t]{2}{*}{ Construct } & \multirow[t]{2}{*}{ Item } & \multirow{2}{*}{$\begin{array}{l}\text { Internal } \\
\text { reliability } \\
\text { Cronbach } \\
\text { alpha }\end{array}$} & \multicolumn{3}{|c|}{ Convergent validity } \\
\hline & & & $\begin{array}{c}\text { Factor } \\
\text { loading }\end{array}$ & $\begin{array}{l}\text { Composite } \\
\text { reliability }\end{array}$ & $\begin{array}{c}\text { Average } \\
\text { variance } \\
\text { extracted }^{b}\end{array}$ \\
\hline \multirow{5}{*}{$\begin{array}{l}\text { Employee } \\
\text { performance }\end{array}$} & EP1 & .739 & .776 & 0.86 & 0.55 \\
\hline & EP2 & .785 & .609 & & \\
\hline & EP3 & .798 & .605 & & \\
\hline & EP4 & .709 & .848 & & \\
\hline & EP5 & .713 & .844 & & \\
\hline \multirow[t]{4}{*}{ Reward } & $\mathrm{R} 1$ & .776 & .880 & 0.90 & 0.69 \\
\hline & $\mathrm{R} 2$ & .826 & .799 & & \\
\hline & R3 & .839 & .772 & & \\
\hline & R4 & .783 & .869 & & \\
\hline \multirow{3}{*}{ Training } & $\mathrm{T} 1$ & .877 & .932 & 0.95 & 0.86 \\
\hline & $\mathrm{T} 2$ & .853 & .947 & & \\
\hline & $\mathrm{T} 3$ & .916 & .905 & & \\
\hline \multirow[t]{3}{*}{$\begin{array}{l}\text { Work } \\
\text { balance }\end{array}$} & WB1 & .766 & .918 & 0.92 & 0.79 \\
\hline & WB2 & .788 & .906 & & \\
\hline & WB3 & .871 & .845 & & \\
\hline
\end{tabular}

Note:

a Composite reliability $=$ (square of the summation of the factor loadings $) /\{$ (square of the summation of the factor loadings $)+($ square of the summation of the error variances) $\}$

$\mathrm{b}$ Average variance extracted $=$ summation of the square of the factor loadings $/$ number of items

\section{Unidimensional}

The evaluation of unidimensional of the proposed scales was assessed by performing exploratory factor analysis (EFA). Factors were extracted based on eigenvalues greater than 1 . 
In addition, they were required to have a significant factor loading greater than 0.4 and a high total variance explained component. A total of four constructs were formed based on their eigenvalues. Bartlett's test of Sphericity and 'Kaiser-Meyer-Olkin' (KMO) measure of sampling adequacy are provided in Table 2. Bartlett's Test of Sphericity determines whether there is a high enough degree of correlation among the variables. Table 2 shows that the test is significant $(\mathrm{p}<0.001)$. The KMOs stat as indicated Table 2 all are greater than the minimum of 0.5 indicating a good degree of correlation. Hence the test reveals a meaningful factor analysis and principal component analysis can be carried out.

Table 2: Exploratory Factor Analysis (EFA)

\begin{tabular}{lccccc}
\hline $\begin{array}{l}\text { Expression regarding } \\
\text { scales }\end{array}$ & $\begin{array}{l}\text { Eigen } \\
\text { value }\end{array}$ & \% variance & $\begin{array}{l}\text { Cronbach } \\
\text { alpha }\end{array}$ & $\begin{array}{l}\text { KMO } \\
\text { Test }\end{array}$ & $\begin{array}{l}\text { Bartlett } \\
\text { test }\end{array}$ \\
\hline $\begin{array}{l}\text { Employee } \\
\text { performance }\end{array}$ & 2.770 & 55.391 & 0.791 & .738 & $\chi^{2}=182.534$ \\
Reward & 2.764 & 69.107 & 0.849 & .802 & $\begin{array}{c}\chi^{2}=174.068 \\
\text { Training }\end{array}$ \\
& 2.585 & 86.172 & 0.919 & .742 & $\chi^{2}=156.198$ \\
& & & & & $\mathrm{P}=0.000$ \\
Work life balance & 2.378 & 79.258 & 0.864 & 0.712 & $\chi^{2}=156.198$ \\
& & & & & $\mathrm{P}=0.000$ \\
\hline
\end{tabular}

\section{Discriminant Validity}

Discriminant validity is achieved when the correlations between the constructs differ significantly from 1 or when Chi-square difference tests indicate that two constructs are not perfectly correlated. As a test of discriminant validity, the correlations among the latent variables were checked to determine if they are significantly different from 1. Table 3 shows the result for the discriminant validity, confirming the validity of all constructs.

Table 3: Correlation Matrix

\begin{tabular}{lccc}
\hline & Performance & Reward & Training \\
\hline Performance & & &
\end{tabular}

Reward

$.577^{* *}$

Training

$.525^{* *}$

$.788^{* *}$

Work Balance

$.717^{* *}$

$.581^{* *}$

$.467^{* *}$

**. Correlation is significant at the 0.01 level (2-tailed). 


\section{Convergent Validity}

Referring to the CFA model, since all the factor loadings are above 0.5 , convergent validity is supported (Steenkamp \& Geyskens, 2006).

\section{Hypotheses Testing}

Structural equation modeling with the AMOS graphical software program was used to test the model and hypotheses shown in Figure 2. The goodness-of-fit of the overall model was assessed with the ratio of the chi-square value to degree of freedom, the root mean square residual (RMR), and the comparative fit index (CFI) ((Bentler, 1990); (Marsh, Balla, \& Hau, 1996)). Satisfactory model fits are indicated by the chi-square value to degree of freedom less than 3.00, RMR value less than 0.05 and CFI values greater than or equal to 0.90 .

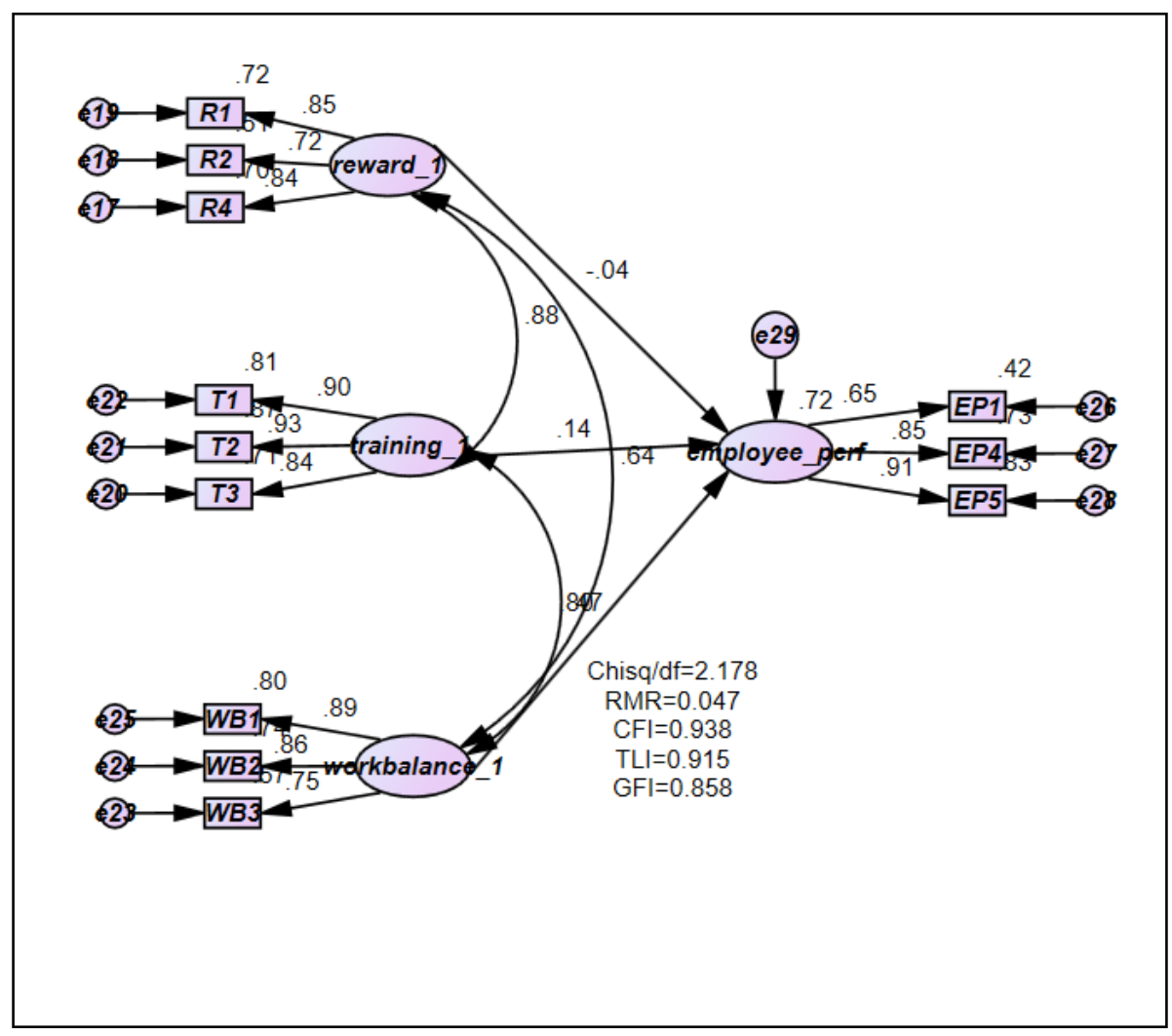

Figure 2: Structural Equation Model using AMOS

Table 4: Regression Weights

\begin{tabular}{lllrrrrl}
\hline Path & & & Estimate & S.E. & C.R. & P & Conclusion \\
\hline employee_perf & $<---$ & workbalance_1 & .726 & .150 & 4.843 & $* * *$ & $\begin{array}{l}\text { H1 is } \\
\text { supported }\end{array}$ \\
employee_perf & $<---$ & reward_1 & -.032 & .214 & -.150 & .881 & $\begin{array}{l}\text { H2 is not } \\
\text { supported }\end{array}$ \\
employee_perf & $<---$ & training_1 & .105 & .167 & .630 & $.529 \begin{array}{l}\text { H3 is not } \\
\text { supported }\end{array}$ \\
\hline
\end{tabular}


This study aims to investigate factors that affecting performance of employee. The result based on work life balance, training and reward. There are three (3) latent variables and 15 indicators that affecting employee performance at workplace. The effect of work life balance on employee performance was hypothesized in $\mathrm{H} 1$. As predicted, work life balance is found has positive impact on employee performance $(\beta=.726, \mathrm{P}<0.001)$ supporting $\mathrm{H} 1$. Next variable is reward impacts on employee performance. Surprisingly the result shows that reward has no significant relationship with employee performance $(\beta=-.032, \mathrm{P}>0.05)$ thus not supporting $\mathrm{H} 2$. Not as expected, it is found that training has no significant relationship with the employee performance with $(\beta=.105, \mathrm{P}>0.05)$ thus not supporting $\mathrm{H} 3$.

\section{Conclusion}

This research has proposed and tested three main hypotheses. The finding reveals that one of these hypotheses was accepted and two were rejected. There is a significant relationship between work-life balance to employee performance. As many studies along with this study has proved the strong relationship between work life balance with employee performance, it is high time for organisations to note that work life balance has to be improved for which the identified factors may be used as means to achieve the same. This will result in enriched employee performance as the study has confirmed that nearly $72 \%$ of employee performance is influenced by work life balance.

From past researches on work-life balance issues, there is directly linked to the many benefits that have been discovered as associated with work-life balance for both the employer and employee (Emslie \& Hunt, 2009); (Jones et al., 2013). In achieving the balancing of professional work requirement and family life it will enhance the performance and productivity by that it will bring positive satisfaction level to employee and organization. Life is wonderful by controlling our self we are able to manage our environment and surrounding. There are many aspects fulfilling our life along with work. Once people would able to balance their roles it goes imbalance. Some people said we live once, the decision we've made on the young ages bring significant affect to our long life. The imbalance of work life bring pressure to people, the mixture roles required people to become creative in managing their life. Improved worklife balance positively impacts their psychological well-being whereas organisations are able to increase affective organisational commitment, job satisfaction, worker engagement, organisational citizenship behaviours and employee productivity through appropriate work-life balance practices and policies (Cegarra-Leiva et al., 2012); (Emslie \& Hunt, 2009); (Jones et al., 2013).

From the beta value $\beta=-.032$, reward has negative impact on employee performance but statistically insignificant. In (Ali \& Ahmed, 2010) study, in long run organizations should have an effective rewards and recognition program in place in order to increase staff morale, motivation, and benefit to the organization. In addition, the survey has shown 89.1 percent of respondents have been working with their current employer less than five years. It is could be an indicator of these respondents are not happy with the reward system which not compensate them accordingly along their service thus contribute to high turnover. As conclusion, if the reward system or scale is improved, it will have a positive impact on the motivation of employees, and vice versa (Hafiza et al., 2011).

In previous studies e.g. (Halawi \& Haydar, 2013) which believes training plays important role in performance of employee with the ability to meet their employee's needs in term of employee knowledge, skills, ability, abilities and behaviour. However, the result of this study shown training does not significantly gives impact on employee performance. It could be most 
probably majority of the respondents are young graduates and just working for the sake of doing part-time or temporary job. There are some cases of their employer do not provide training to part-time workers because of cost factor.

\section{Recommendation}

All organizations in workplace both public and private should have a strong desire to improve the efficiency and effectiveness of their employees. This cannot be accomplished without a profound understanding of the factors that influence their employee's performance. Every organization should have documented the factors that can influence the employees and go through from time to time to make sure that it is stable.

In making sure the employee in high working satisfaction level, organization play important role towards employee commitment, loyalty and performance. An organization that care and concern for the hardness of their employee would able to create the policies, guidelines or code of conduct in the organization in making sure the employee sustains or increase their performance level. The policies apply not only accelerate performance but it also able to decrease the employee layoff and turnover (Devi \& Rani, 2012).

\section{References}

Aboazoum, H. M. E., Nimran, U., \& Musadieq, M. Al. (2015). Analysis Factors Affecting Employees Job Performance in Libya. IOSR Journal of Business and ManagementVer. I. https://doi.org/10.9790/487X-17714249

Abualoush, S. H., Obeidat, A. M., Tarhini, A., Masa'deh, R., \& Al-Badi, A. (2018). The role of employees' empowerment as an intermediary variable between knowledge management and information systems on employees' performance. VINE Journal of Information and Knowledge Management Systems. https://doi.org/10.1108/VJIKMS08-2017-0050

Abualoush, S., Masa'deh, R., Bataineh, K., \& Alrowwad, A. (2018). The role of knowledge management process and intellectual capital as intermediary variables between knowledge management infrastructure and organization performance. Interdisciplinary Journal of Information, Knowledge, and Management. https://doi.org/10.28945/4088

Ali, R., \& Ahmed, S. (2010). The Impact Of Reward And Recognition Programs On Employee's Motivation And Satisfaction: An Empirical Study. International Journal of Business and Management. https://doi.org/10.5539/ijbm.v5n2P159

Allen, M. J. (1984). Book Review : Essentials of Psychological Testing Lee J. Cronbach New York: Harper \& Row, 1984, 630pp, approx. \$27.50. Applied Psychological Measurement. https://doi.org/10.1177/014662168400800314

Anderson, J. C., \& Gerbing, D. W. (1988). Structural Equation Modeling in Practice: A Review and Recommended Two-Step Approach. Psychological Bulletin. https://doi.org/10.1037/0033-2909.103.3.411

Bagozzi, R. P., \& Yi, Y. (1988). On the evaluation of structural equation models. Journal of the Academy of Marketing Science. https://doi.org/10.1007/BF02723327

Bataineh, K. adnan. (2019). Impact of Work-Life Balance, Happiness at Work, on Employee Performance. International Business Research. https://doi.org/10.5539/ibr.v12n2p99

Bentler, P. M. (1990). Comparative fit indexes in structural models. Psychological Bulletin. https://doi.org/10.1037/0033-2909.107.2.238

Cegarra-Leiva, D., Eugenia Sánchez-Vidal, M., \& Cegarra-Navarro, J. G. (2012). Understanding the link between work life balance practices and organisational outcomes in SMEs: The mediating effect of a supportive culture. Personnel Review. https://doi.org/10.1108/00483481211212986 
Claes, F., \& David F., L. (1981). Evaluating Structural Equation Models with Unobservable Variables and Measurement Error. Journal of Marketing Research.

Devi, A. C., \& Rani, S. S. (2012). Personality and work - Life Balance. Journal of Contemporary Research in Management.

Downes, P. E., \& Choi, D. (2014). Employee reactions to pay dispersion: A typology of existing research. Human Resource Management Review. https://doi.org/10.1016/j.hrmr.2013.08.009

Emslie, C., \& Hunt, K. (2009). "Live to work" or "work to live"? A qualitative study of gender and work-life balance among men and women in mid-life. Gender, Work and Organization. https://doi.org/10.1111/j.1468-0432.2008.00434.x

Hafiza, N. S., Shah, S. S., \& Jamsheed, H. (2011). Relationship between Rewards and Employee's Motivation in the Non-Profit Organizations of Pakistan. Business Intelligence Journal.

Halawi, A., \& Haydar, N. (2013). Effects of Training on Employee Performance: A Case Study of Bonjus and Khatib and Alami Companies. International Humanities Studies.

Hijry, H., \& Haleem, A. (2017). Study the factors that influence employees performance in the steel factory, Saudi Arabia. Proceedings of the International Conference on Industrial Engineering and Operations Management.

Huang, W. R., \& Jao, Y. J. (2016). Comparison of the influences of structured on-the-job training and classroom training approaches on trainees' motivation to learn. Human Resource Development International. https://doi.org/10.1080/13678868.2015.1096636

Hunter, J. E. (1986). Cognitive ability, cognitive aptitudes, job knowledge, and job performance. Journal of Vocational Behavior. https://doi.org/10.1016/00018791(86)90013-8

Ibrar, M., \& Khan, O. (2015). The Impact of Reward on Employee Performance (A Case Study of Malakand Private School). International Letters of Social and Humanistic Sciences. https://doi.org/10.18052/www.scipress.com/ilshs.52.95

Jones, F., Burke, R. J., \& Westman, M. (2013). Work-life balance: A psychological perspective. In Work-Life Balance: A Psychological Perspective. https://doi.org/10.4324/9780203536810

Khan, K., \& Baloch, N. A. (2017). Impact of Training on Employee Development and Other Behavioral Outcomes: A Case of Public Accountant Trainees in Khyber Pakhtunkhwa. Journal of Managerial Sciences.

Kim, H. K. (2014). Work-Life Balance and Employees' Performance: The Mediating Role of Affective Commitment. An International Journal.

Lakra, N. R. (2016). Assessment of Employee Training: The Case of Steel Industry in India. The IUP Journal of Management Research, .

Lin, S.-R., \& Hsu, C.-C. (2017). Study of Impact on -Job Training on Job Performance of Employees in Catering Industry. The International Journal of Organizational Innovation Num.

Marsh, H., Balla, J., \& Hau, K.-T. (1996). An Evaluation of Incremental Fit Indices: A clarification of Mathematical and Empirical Properties. Advanced Structural Equation Modeling: Issues and Techniques.

Mendis, M. D. V. S., \& Weerakkody, W. A. S. (2018). The impact of work life balance on employee performance with reference to telecommunication industry in Sri Lanka: a mediation model. Kelaniya Journal of Human Resource Management. https://doi.org/10.4038/kjhrm.v12i1.42

Nunnally, J. C. (1979). Psychometric Theory: Secon d Edition. Applied Psychological Measurement. 
Ramlall, S. J. (2008). Enhancing employee performance through positive organizational behavior. Journal of Applied Social Psychology. https://doi.org/10.1111/j.15591816.2008.00360.x

SHAIKH, M. R., TUNIO, R. A., \& SHAH, I. A. (2017). Factors Affecting to Employeeâ€ TM Performance. A Study of Islamic Banks. International Journal of Academic Research in Accounting, Finance and Management Sciences. https://doi.org/10.6007/ijarafms/v7-i1/2722

Soomro, A. A., Breitenecker, R. J., \& Shah, S. A. M. (2018). Relation of work-life balance, work-family conflict, and family-work conflict with the employee performancemoderating role of job satisfaction. South Asian Journal of Business Studies. https://doi.org/10.1108/SAJBS-02-2017-0018

Steenkamp, J. B. E. M., \& Geyskens, I. (2006). How country characteristics affect the perceived value of web sites. Journal of Marketing. https://doi.org/10.1509/jmkg.70.3.136

Zahid Hussain Bhat, Z. H. B. (2011). Impact of Training on Employee Performance: A Study of Retail Banking Sector in India. Indian Journal of Applied Research. https://doi.org/10.15373/2249555x/june2013/97 